\title{
Restabelecimento dos plantões de policiais
}

Conselho Nacional de Justiça (CNJ)

PEDIDO DE PROVIDÊNCIAS № 0003295-89.2011.2.00.0000

RELATOR: CONSELHEIRO GILBERTO VALENTE MARTINS

REQUERENTE: SINDICATO DOS DELEGADOS DE POLÍCIA DE MINAS GERAIS

REQUERIDO: ROBERTO CARLOS DE MENEZES

ASSUNTO: $\quad$ TJMG - Providências - Portaria no ${ }^{0}$ 02/GAB/3 $3^{\mathrm{a}}$ DRPC $/ 18^{\circ}$

DPC - Plantão Policial - Delegado de Polícia Suspensão - Ação Civil Pública - Intervenção - Ministério Público - Controle Interno - Polícia Civil - Ilegalidade - Decisão Judicial - Contrariedade Mudança - Portaria - Competência - Superintendência Polícia Civil

Acórdão

RECURSO ADMINISTRATIVO NO PEDIDO DE PROVIDÊNCIAS. TRIBUNAL DE JUSTIÇA DE MINAS GERAIS. DECISÃO JUDICIAL DE PRIMEIRO GRAU. AÇÃO CIVIL PÚBLICA. IMPOSSIBILIDADE DE REVISÃO DE DECISÃO JUDICIAL. PRECEDENTES DO SUPREMO TRIBUNAL FEDERAL E DO CONSELHO NACIONAL DE JUSTIÇA. DECISÃO MONOCRÁTICA PELA IMPROCEDÊNCIA DO PEDIDO. RECURSO CONHECIDO A QUE SE NEGA PROVIMENTO.

01 - Revisão de decisão judicial só é passível mediante interposição dos recursos previstos na Constituição Federal e nas leis processuais. 
02 - Ao Conselho Nacional de Justiça cabe o controle da atuação administrativa e financeira do Poder Judiciário e cumprimento dos deveres funcionais dos magistrados. Entretanto, dentro destas atribuições elencadas no art. 103-B, não alcança a análise e consequente reforma de mérito da decisão judicial.

03 - Recurso conhecido a que se nega provimento, mantida a decisão monocrática do Relator.

\section{Vistos etc.}

Trata-se de Recurso Administrativo interposto pelo SINDICATO DOS DELEGADOS DE POLÍCIA DE MINAS GERAIS, contra a decisão monocrática do meu antecessor, Conselheiro Felipe Locke Cavalcanti, que em razão da manifesta improcedência do pedido, determinou o arquivamento do processo no qual foi solicitada providência quanto à decisão judicial que determinou o restabelecimento de plantões policiais na cidade de Alpinópolis.

Inconformado com a decisão proferida, o requerente reitera os argumentos da inicial, salientando que: "não se pede a revogação de uma decisão judicial, mas sim que seja aberto procedimento para que o Magistrado dê explicações a este conselho sobre o porquê de uma decisão em contrariedade a Legislação vigente...".

Foram solicitadas informações em razão do recurso interposto, sendo estas devida e oportunamente prestadas.

É o relatório.

A decisão monocrática está assim redigida:

A presente insurgência é ato absolutamente estranho às finalidades do Conselho Nacional de Justiça.

Com efeito, pretende a suplicante que este órgão reexamine uma decisão judicial.

Não cabe ao Conselho Nacional de Justiça o desfazimento de decisões proferidas em processos judiciais. Ao Conselho incumbe, nos termos da Constituição Federal, apenas, o controle administrativo, financeiro e disciplinar dos Tribunais e Juízes de Direito.

Logo, o pedido de revogação de uma decisão proferida em processo promovido pelo Ministério Público, que determinou o restabelecimento de plantões policiais, não é incumbência deste órgão de controle. 
Ante o exposto, julgo improcedente o presente pedido e determino o arquivamento do presente processo.

O requerente, pela via recursal, insiste nos pedidos iniciais. Reitera a informação de que: "o Conselho é sim incumbido nos termos da Constituição Federal do controle disciplinar dos Tribunais e este é um caso de controle disciplinar e administrativo, pois verifica-se que não foram observados pelo Ilmo. Juiz a Legislação local do Estado de Minas Gerais".

Os argumentos do recorrente não foram capazes de modificar nosso entendimento. Para que se esclareça, o pedido inicial foi assim externado pelo requerente: "que este Colendo Conselho interceda acerca das irregularidades aqui mencionadas e restabeleça a ordem jurídica legal, para que no futuro não tenhamos nem interferência do MP no controle interno da Polícia Civil e que o magistrado cumpra seu dever de juiz no que tange ao respeito da Legislação vigente".

Parece evidente, como sobredito, que o Conselho Nacional de Justiça, embora competente para o controle da atuação administrativa do Poder Judiciário, nos termos do parágrafo $4^{\circ}$ do art. 103-B da Constituição da República, não pode avançar além dos limites impostos pela norma constitucional, de modo a indevidamente atingir decisão judicial ou nela interferir mesmo que para "restabelecer a ordem legal" mormente presentes recursos processuais possíveis para a revisão da decisão judicial.

Já salientou o Conselheiro Alexandre de Moraes quando da decisão do PCA 213:

Torno a repetir a possibilidade constitucional e legal para tanto, mas também, entendo importante analisarmos a conveniência do CONSELHO NACIONAL DE JUSTIÇA passar a ser utilizado rotineiramente como instrumento de alteração de competência jurisdicional, a fim de, por via oblíqua, afastar decisões jurisdicionais contrárias aos interesses dos requerentes, sem que haja evidente decisão teratológica a motivar e a justificar a atuação desse Colegiado.

Neste mesmo sentido colhemos os seguintes precedentes:

Procedimento de Controle Administrativo. Matéria sub judice. "Inarredável a competência deste Conselho para controle da atuação administrativa do Poder Judiciário, nos termos do parágrafo $4^{\circ}$ do 
artigo 103-B da Constituição Federal, mas não deve o CNJ avançar no debate de sorte a atingir eventual decisão judicial, ou nela intervir, por razão de segurança jurídica e respeito à função jurisdicional, evitandose possíveis pronunciamentos conflitantes" (CNJ - PCA 631 - Rel.

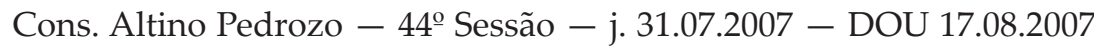
- Ementa não oficial).

Pedido de Providências. Processo Administrativo da Corregedoria Permanente de Cartórios. Alegação de nulidades ocorridas em vários lançamentos de matrícula do Registro de Imóveis. Pedido formulado por advogado sem procuração com fins específicos e em nome próprio. Petição inicial inepta e irregularidades inexistentes. Questão posta já judicializada. - "A parte interessada não pode fazer uso, a um só tempo, dos procedimentos administrativos excepcionais assegurados pelo art. 103-B, $\$ 4^{\circ}$ da $\mathrm{CF} / 88$ perante o $\mathrm{CNJ}$ e dos meios judicialiformes tendentes a obter a coisa julgada definitiva no âmbito do Poder Judiciário" (CNJ - PP 1400 - Rel. Cons. Rui Stoco - 47º Sessão j. 11.09.2007 - DJU 27.09.2007).

Colocando fim a discussão da matéria, está o posicionamento do Supremo Tribunal Federal, que reiteradamente vem explicitando que:

Não se desconhece que o Conselho Nacional de Justiça - embora incluído na estrutura constitucional do Poder Judiciário - qualifica-se como órgão de caráter eminentemente administrativo, não dispondo de atribuições institucionais que lhe permitam exercer fiscalização da atividade jurisdicional dos magistrados e Tribunais. (MS 27.148 DF - trecho do voto do Relator Ministro Celso de Mello)

Por outro lado, em regra, mesmo a reclamação disciplinar não é meio idôneo para questionamento de erro de forma ou conteúdo de decisão judicial. É o entendimento do Plenário:

Recurso Administrativo. Reclamação Disciplinar. Atos Judiciais. Arquivamento Mantido. - "A Reclamação Disciplinar não é meio idôneo para questionamento de erro de forma ou conteúdo de decisão judicial, nem tampouco é sucedâneo do meio processual destinado à arguição de parcialidade do órgão jurisdicional. Arquivamento que 
encontra previsão no art. 31, inciso I, do RICNJ. Recurso a que se nega provimento" (CNJ - RD 215 - Rel. Cons. Antônio de Pádua Ribeiro

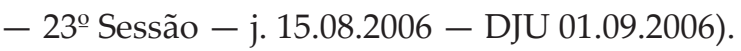

Quanto aos demais aspectos da narrativa recursal, nada há a se acrescentar na decisão monocrática.

Por todo o exposto, o recurso é conhecido sendo negado seu provimento, mantida a decisão monocrática do Relator.

\section{Conselheiro Gilberto Valente Martins}

Relator 